\title{
Popis slikovnih priloga
}

O smrti na Desničinim susretima. Predgovor (Ivana Cvijović Javorina i Drago Roksandić)

Sl. 1. Desničini susreti 2017. (design: Dejan Dragosavac Ruta)

Haronova dobra. Antički motivi u tanatičkom repertoaru Vladana Desnice (Bruna KuntićMakvić)

Sl. 1. Glasoviti muževi staroga vijeka. Korice izdanja koje je priredio Marko Car, primjerak iz privatne knjižnice, Zagreb

Sl. 2. Marko Car, Glasoviti muževi staroga vije$k a$, naslovnica s Carevim inicijalima (primjerak iz privatne knjižnice)

Sl. 3. Otto Seemann, Mythologija Grka i Rimljana, Zagreb 1890. (primjerak iz privatne knjižnice)

Sl. 4. Himera iz Arezza, bronca, lijevanje à cire perdue (5. - 4. st. pr. Kr., etruščanska umjetnost), Firenze, Museo archeologico nazionale (snimila BKM)

Sl. 5. Paul Gustave Doré, Haron, drvorez (1857.) (https://bs.m.wikipedia.org/wiki/Datoteka:Charon_by_Dore.jpg)

Sl. 6. Mirko Rački, Prijelaz preko Aheronta, ulje na platnu (1910.), Muzej za umjetnost i obrt, Zagreb (https://www.europeana.eu/portal/ hr/record/2026118/_MG_0843.html)

Sl. 7. Mirko Rački, S onu stranu Acherona, tuš i akvarel na papiru, (1907.), Galerija umjetnina, Split. Fotodokumentacija Galerije. Snimio Valentino Bilić Prcić

Tanatologike Vladana Desnice - igre poetike i smrti (Bojan Jović)

Sl. 1. Fragment autografa romana Pronalazak Athanatika (Osobna ostavština Vladana Desnice)

Sedefasti odsjev vječnosti. Tanatološki aspekti književnog djela Vladana Desnice (Vladan Bajceta)

Sl. 1. Pismo Vladana Desnice Tomislavu Tanhoferu o Ljestvama Jakovljevim (Osobna ostavština Vladana Desnice)
Slovenačka recepcija Vladana Desnice i tematizovanja smrti u njegovim delima (Marija Mitrovic')

Sl. 1. In memoriam Vladanu Desnici u listu Delo (Tone РотокаR, „Ob smrti Vladana Desnice“, Delo [Ljubljana], br. 63, 7.3. 1967., 5)

Dramaturgija slobode i smrti ili o Ljestvama Jakovljevim Vladana Desnice u svetlu Sartrove teorije pozorišta situacija (Aleksandra Kuzmić)

Sl. 1. Pismo dramaturga Jovana Ćirilova Vladanu Desnici (Osobna ostavština Vladana Desnice, dalje: OOVD)

Sl. 2. Fotografija sa čitaćih proba Ljestava Jakovljevih 1960. godine: Tomislav Tanhofer, Viktor Starčić i Vladan Desnica (OOVD)

Časopis kao amblem poslednjeg časa: međusobna uslovljenost motiva smrti i motiva periodične štampe u pripovetkama Vladana

Desnice (Stanislava Barać)

Sl. 1. Astrološka predviđanja za 1836. godinu u Srbsko-dalmatinskom almanahu (АЮБИТЕАЬ ПРОСВБШТЕНІЯ. СРБСКО-А АМАТИНСКІЙ ААМАНАХЬ ЗА ИБТО 1836. ИзАао га на свет Теодор Петрановић, обои права доктор. У КарАштадту, печатано у Типографији Иоана $\mathrm{H}$. Претнера, 21-22)

Groteskna slika tijela u Olupinama na suncu Vladana Desnice (Sanja Šakić)

Sl. 1. Korice sarajevskog izdanja zbirke novela Olupine na suncu iz 1962. godine (Svjetlost, Sarajevo 1962., Biblioteka „Džepna knjiga“)

\section{Thanatopolitika i imortalizam u Desničinu} Pronalasku Athanatika (Vinko Drača)

Sl. 1. Pregled poglavlja nedovršena romana Pronalazak Athanatika (Osobna ostavština Vladana Desnice)

Vladan Desnica, prevoditelj i komentator Foscolovih Grobova (Sanja Roić i Iva Grgić Maroević)

Sl. 1. Redigirani strojopis Desničinih bilješki uz prijevod Grobova Uga Foscola (Obiteljska ostavština Vladana Desnice) 
U iščekivanju smrti ili preplitanja života i smrti u Baraci 5 be Miroslava Krleže i Rekonvalescentima Dragiše Vasića (Iva Tešić)

Sl. 1. Korice prvog izdanja zbirke Hrvatski bog Mars s ilustracijom Ljube Babića (Antikvarijat vremeplov, http://www.antikvarijatvremeplov.hr/krle\%C5\%BEa-hrvatski-bogmars-proizvod-6732)

Šašava besmrtnost i garava smrt: predstave ljudske smrti u poeziji za decu i mlade Miroslava Antića (Vladimir Vukomanović Rastegorac)

Sl. 1. Ilustracija Miće Mihajlovića u Šašavoj knjizi (Izabrana dela Miroslava Antića, Dnevnik, Novi Sad 1982., 41)

Uloga smrti u njemačkoj filozofiji egzistencije međuratnoga perioda i njezina recepcija $u$ misli Stjepana Zimmermanna (Matko Globačnik)

Sl. 1. Stjepan Zimmermann (Hrvatska enciklopedija, www.enciklopedija.hr/natuknica. aspx?id=67251)

Grobni spomenici iz sjeverozapadne Hrvatske u svjetlu odnosa rimske antike prema smrti (Branka Migotti)

Sl. 1. Stela Tita Flavija Ateboda (2. stoljeće), Odra kod Zagreba (Arheološki muzej u Zagrebu)

Sl. 2. Nadgrobna ploča Leburne (4. stoljeće), Sisak (Mađarski narodni muzej, Budimpešta)

Sl. 3. Stela robovske obitelji (2. stoljeće), Donji Čehi (Arheološki muzej u Zagrebu)

Sl. 4. Sarkofag Romanije Nevije (3. stoljeće), Sisak (Arheološki muzej u Zagrebu)

Epitafi srednjega vijeka: „knjige života i smrti“" (Mirjana Matijević Sokol)

Sl. 1. Sarkofag s epitafom opatice Ivane na Manastirinama u Solinu (Ivan BAsıć, „CIL III 9551 i njegovi tumači“, Tusculum, 1/2008., 85)

Sl. 2. Epitaf kraljice Jelene, Muzej hrvatskih arheoloških spomenika, Split (Tomislav Raukar, Hrvatsko srednjovjekovlje. Prostor, ljudi, ideje, Zagreb 1997., 241)

Sl. 3. Grobnica s natpisom opatice Vekenege, kapitul samostana sv. Marije u Zadru (T. RAUKAR, Hrvatsko srednjovjekovlje, 61)

Sl. 4. Natpis na ploči u zidu iznad bifore na grobnici opatice Vekenege, kapitul samosta- na sv. Marije u Zadru (T. Raukar, Hrvatsko srednjovjekovlje, 62)

Sl. 5. Epitaf Tome Arhiđakona, crkva sv. Frane na Rivi u Splitu (T. Raukar, Hrvatsko srednjovjekovlje, 371)

Sl. 6. Nadgrobni spomenik Ratkajevih u crkvi sv. Marije u Lepoglavi (Josip ŚTimaC i dr. [ur.], Ratkaji Velikotaborski u hrvatskoj povijesti i kulturi 1502-1793. u povodu 200-te obljetnice izumrća. Grad Veliki Tabor, 11. rujna-10. listopada 1993., 22)

Oporuke zagrebačkih građana s kraja 17. stoljeća u gradskim knjigama Zapisnika izjavnica (Protocolla fassionum) (Zvjezdana Sikirić Assouline)

Sl. 1. Zapisnik izjavnica (lat. Protocollum fassionum) (Državni arhiv u Zagrebu, Poglavarstvo grada Zagreba, 1657 [77], Zapisnik izjavnica [Protocollum fassionum] za godine 1693. - 1714.)

Sl. 2. Početak oporuke Helene Veselinović (isto)

Duh moderne: od kulture življenja do kulture smrti. Fenomen samoubojstva u Europi i Hrvatskoj (Filip Šimetin Šegvić i Nikolina Šmetin Šegvić)

Sl. 1. Édouard Manet, Samoubojstvo (između 1877. i 1881.) (http://www.manet.org/le-suicide.jsp)

Sl. 2. Gustav Klimt, studija za alegorijsku sliku Jurisprudencija u Svečanoj sali Sveučilišta u Beču (1898.) (https://commons.wikimedia. org/wiki/File:Klimt___Gemalter_Kompositionsentwurf_zur_Jusisprudenz.jpeg)

Sl. 3. George Grosz, Samoubojstvo (1916.) (https://www.tate.org.uk/art/artworks/grosz-suicide-t02053)

Kad smrt poždere smrt: utjecaj pandemije španjolske gripe iz 1918. godine na dinamiku patocenične promjene u sjevernoj Hrvatskoj (Nikola Anusićć)

Sl. 1. Stope mortaliteta od tuberkuloze u Banskoj Hrvatskoj od 1901. do 1910. godine (izračun autora prema: Ana BorovečKI Ira Gjenero-Margan, „Epidemiological Analysis of Tuberculosis in the Kingdom of Croatia and Slavonia during 1901 - 1910“, Croatian Medical Journal, 43/2002., br. 3, 350-354) 
Sl. 2. Spolna struktura umrlih od tuberkuloze u sjevernoj Hrvatskoj od 1908. do 1919. godine (izračun autora)

Sl. 3. Mortalitet od španjolske gripe u sjevernoj Hrvatskoj tijekom drugoga epidemijskog vala (izračun autora)

Sl. 4. Ostvarene i očekivane stope mortaliteta od tuberkuloze od 1901. do 1921. godine (izračun autora prema: Vladimir ĆEPUlić, Suzbijanje tuberkuloze u Zagrebu, Zagreb 1940.)

Hrvatsko državno kazalište u Zagrebu 1941. godine - dani smrti, straha i poniženja

(Snježana Banović)

Sl. 1. Policijski karton Margarete Froman (Hrvatski državni arhiv, dalje: HDA)

Sl. 2. Otisci prstiju Dubravka Dujšina uzeti nakon uhićenja 1941., 1942. i 1944. godine (vlasnišstvo obitelji Delale)
Sl. 3. Policijski karton Ivana Štrka (HDA)

Sl. 4. Policijski karton Rade Sladića (HDA)

Sl. 5. Policijski karton Krste Hegedušića (HDA)

Dva ispraćaja Vladana Desnice (Monica

Priante)

Sl. 1. Oproštaj od Vladana Desnice ispred mrtvačnice na zagrebačkom Mirogoju (Večernji list, br. 2359, 7. 3. 1967., 8)

Sl. 2. Oproštaj od Vladana Desnice u Islamu Grčkom (Osobna ostavština Vladana Desnice, dalje: OOVD)

Sl. 3. Reprodukcija plakata Usmena Zadarska revija. Vladan Desnica in memoriam (OOVD)

Sl. 4. Ispred odra Vladana Desnice (OOVD)

Sl. 5. Okupljeno mnoštvo ispred Kule Stojana Jankovića u Islamu Grčkom na sprovodu Vladana Desnice (OOVD) 